\title{
Current Status of Las Tablas de Daimiel National Park Wetland and Actions Required for Conservation
}

\author{
Sandra Bravo-Martin ${ }^{1}\left(\mathbb{D}\right.$, Miguel Mejías ${ }^{2}$, Francisco J. García-Navarro ${ }^{3}$ and \\ Raimundo Jiménez-Ballesta ${ }^{4, *(D)}$ \\ 1 Department of Vegetal Production and Agricultural Technology, University of Castilla-La Mancha, \\ H.T.S of Agronomists, Ronda de Calatrava 7, 13017 Ciudad Real, Spain; sandra.bravo@uclm.es \\ 2 Department of Research and Geological Resources, Geological Survey of Spain, 28003 Madrid, Spain; \\ m.mejias@igme.es \\ 3 Department of Agroforestry Science and Technology and Genetic, University of Castilla-La Mancha, \\ H.T.S of Agronomists, Ronda de Calatrava 7, 13017 Ciudad Real, Spain; FcoJesus.Garcia@uclm.es \\ 4 Department of Geology and Geochemistry, Autónoma University, 28049 Madrid, Spain \\ * Correspondence: raimundo.jimenez@uam.es
}

Received: 31 May 2019; Accepted: 19 June 2019; Published: 21 June 2019

\begin{abstract}
Wetlands are complex ecosystems that play multiple roles. 'Las Tablas de Daimiel National Park' (TDNP) undoubtedly plays a role in several ecosystem services and provides a connection between nature, farmers, scientists, residents, and other stakeholders. The state of degradation and/or vulnerability of this ecosystem (with a series of socio-economic implications) have led the publication of numerous articles. The work reported here provides a description of the growing importance of this wetland within the rural landscapes of La Mancha and emphasizes its state of degradation, mainly since pedological point of view. In this way, particular attention is required to assure the conservation of the Tablas of Daimiel Wetland; thus, several measures are proposed to improve the conservation of this area as to control and prohibit any dumping of any type of waste in the park or in its vicinity.
\end{abstract}

Keywords: historical events; environmental crisis; management; human interference; consequence

\section{Introduction}

Wetlands are amongst the ecosystems with the greatest biodiversity and biological activity [1] and they play a key role in the maintenance of different ecosystem values. In this context, wetlands range from extensive coastal lagoons to small ponds of just a few square meters in surface area. These ecosystems are considered to be among the most important carbon sinks and they have a marked influence on climate change [2]. However, the capacity for carbon sequestration by wetlands and their influence on climate change is not well understood by society.

The role of the wetlands and its soils as key factors to achieve the sustainable goals of the United Nations and the land degradation neutrality has been shown by Keestra [3]. Worldwide, wetlands are threatened for different reasons: alteration of their hydrogeological characteristics, unsustainable water use, draining of wetlands, discharge of waste or contaminated water, local extinction of fauna, destruction of vegetation, excessive loading of nutrients, pressure due to tourism infrastructure, and vandalism, amongst others [4-6]. In this sense, agricultural expansion and intensification, both traditional and modern (especially irrigation), industrialization, and the dumping of waste that 
has not been sufficiently treated are factors that contribute to the change in the original 'status' of wetlands and these favor wetland degradation and do not take into account the vulnerability of such areas. Furthermore, long-term soil degradation induces large shifts in dominant species and their associated ecosystem functions $[7,8]$.

The Mediterranean region is characterized by hot dry summers and humid, cool winters. Wetlands in this region are varied, and there are many different types. One of these wetlands is known as Tablas de Daimiel (TDNP); its characteristics and, in some cases, human impact have been described by various authors as [9-20]. La Mancha region is prone to suffer periods of recurrent drought and increasing aridification, and as a consequence, the effects of the loss of quality of the TDNP wetland could be catastrophic as happen in other wetlands [21].

Despite the fact that a large amount of research has been carried out on the TDNP and measures for the protection, restoration and sustainable use have been proposed [22,23] and amongst others, the fact is that, as with other wetlands [24], there is little social interest in the functioning, state of degradation and/or vulnerability of this area.

There are a large number of publications about the TDNP at the forefront of the border between soil, water and vegetation $[11,17,20,25-32]$, in addition to the references provided above. The common theme in all of these works is that they concern a special wetland that provides a unique habitat and retains water during dry periods, which is critical for the survival for a large amount of flora and fauna in a semi-arid environment. For example, Cirujano et al. [11] described a series of iconic plant species and their changes over time; Mejías et al. [31] studied the piezometric evolution of the surroundings of Las Tablas de Daimiel, Mejias [17] evaluated the geological, hydrogeological, social and cultural characteristics of the wetland, and Jiménez-Ballesta [32] highlighted the presence of peaty soils (with or without salinity) that are very different from the Alfisols, Inceptisols or Entisols [33] that are common in the regional area of La Mancha.

Despite the research carried out on the TDNP it look like that there is need to review the current state of this ecosystem and to identify the actions required for its conservation. Starting from the basis that the sustainable management of the TDNP requires the maintenance of biodiversity and other vital functions and processes that occur, such as the nutrient and water cycle, the main objective of this study was to assess the current state of degradation of the Tablas de Daimiel National Park and to suggest additional measures to those already in existence for the conservation and management of this area. These goals were achieved by analyzing new and old data from different sources published by the authors of this work. This process was carried out by reviewing the observed processes and proposing actions or control measures that would prevent the degradation and even the disappearance of this natural site.

\section{Study Area}

\subsection{Geological Structure}

The Tablas de Daimiel National Park is located in the northwestern zone of the natural region of La Mancha, more specifically in the western third of the geological domain of the Manchega Plain (Figures 1-3). This domain is delimited to the west by the Hespérico Massif, to the north by the domain of the Sierra de Altomira, to the east by the Castellana branch of the Iberian mountains and to the south by the post-Alpine domain including the Campos de Calatrava volcanic field. This national park is part of the La Mancha Humid Biosphere Reserve, which was declared in 1981 and has an area of 25,000 hectares. The wetland floodplain (TDNP) currently covers 3030 ha in the Park area and 5410 ha in the Protected area; the socioeconomic area of influence is 82,174 ha [17]. 


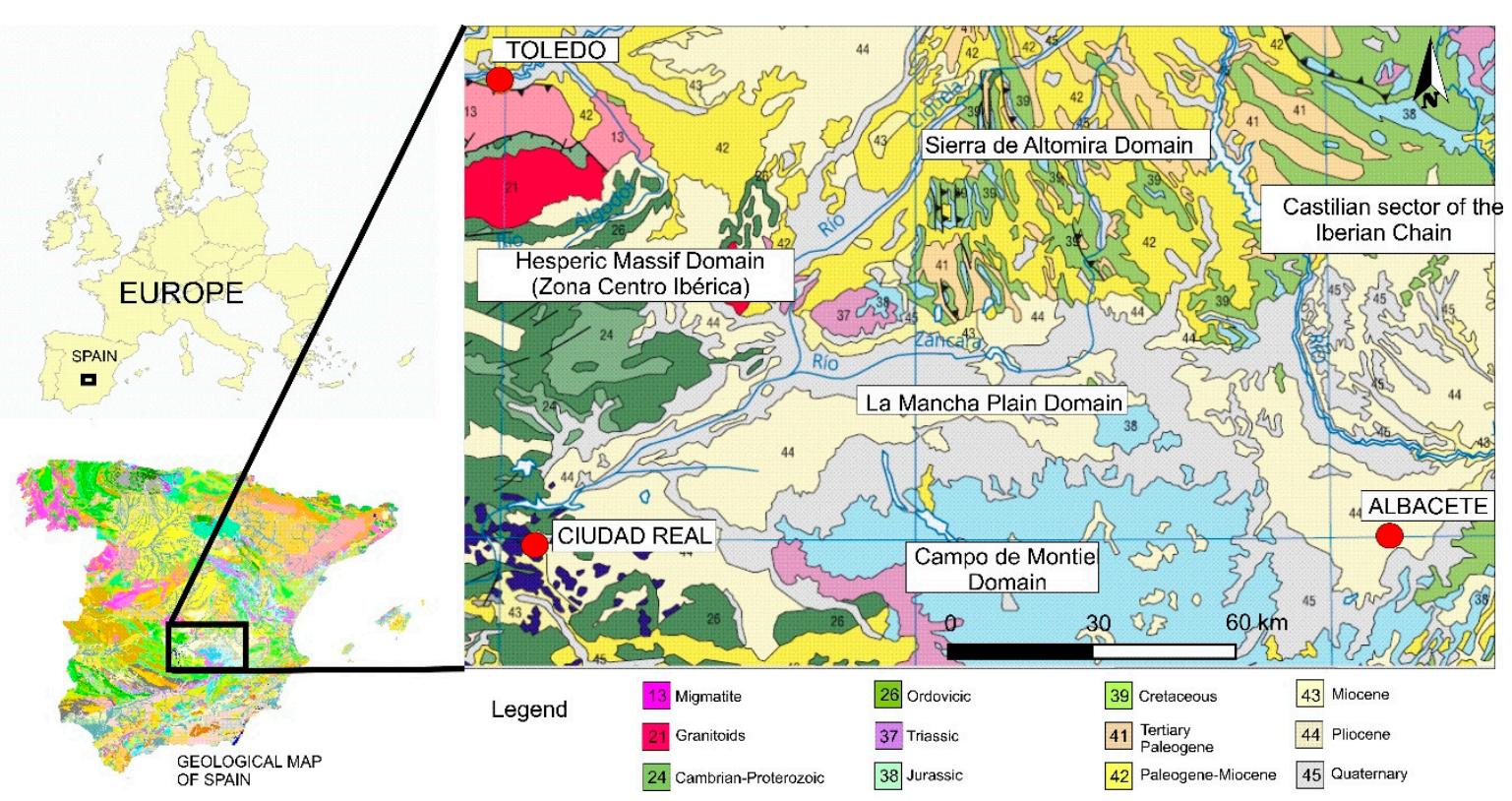

Figure 1. Location of the study area according to geological domains.

The filling materials in the bassin in which the TDNP is located are of Cenozoic age and are arranged directly on the socle, which ascends progressively until the sedimentary basin closes, emerging in the western sector of the Manchega Plain. On the surface, the Cenozoic materials that fill the basin give rise to an extensive plain formed from the continental sedimentary series that characterizes the flat morphology of the Manchega Plain. The socle is made up of quartzite and Paleozoic slate, and the neogeneous series is arranged in a jarring manner upon this, with a basically detrital lower section and a carbonated upper section.

It should be noted that a Pliocene carbonated level is present in certain areas and there is significant karstification, especially in the TDNP and its surrounding environment, which marks the main elements of the landscape. There is also a notable presence of sinkholes, which are circular or semi-circular in shape and have diameters that can be more than 100 meters in some cases $[27,34]$.

\subsection{Hydrology Conditions of the TDNP}

Hydrologically, the TDNP is in the upper basin of the Guadiana River in the Groudwater Body (GWB) called 'Mancha Occidental I', which has an area of $2002.80 \mathrm{~km}^{2}$. The relief is smooth, with an altitude that ranges between 600 and 750 meters above sea level (m.a.s.l.). The main fluvial courses that run through the GWB are Gigüela, Záncara, Azuer, and Guadiana. These rivers are currently scarce in flow and are highly anthropically modified. The basin drains from east to west, with its waters converging in the surroundings of the TDNP (Figure 2).

The fluvial network, which is conditioned by the confluence of the Gigüela and Guadiana rivers, is the key to this unique natural environment. The reduced slope of the Gigüela river favors the overflow of its waters in a wide shallow floodplain (Figure 3). Groundwater plays an essential role since the Aquifer System 23, currently integrated by the GWB (Mancha Occidental I; Mancha Occidental II and Rus-Valdelobos), discharges its waters through the springs located at the site called 'Los Ojos del Guadiana'. This gives rise to the birth of this river, which reaches the wetland a few kilometers downstream. This distinctive feature in the quality of the confluent waters gives the system a uniqueness and environmental value that make it a special ecosystem in Europe. 


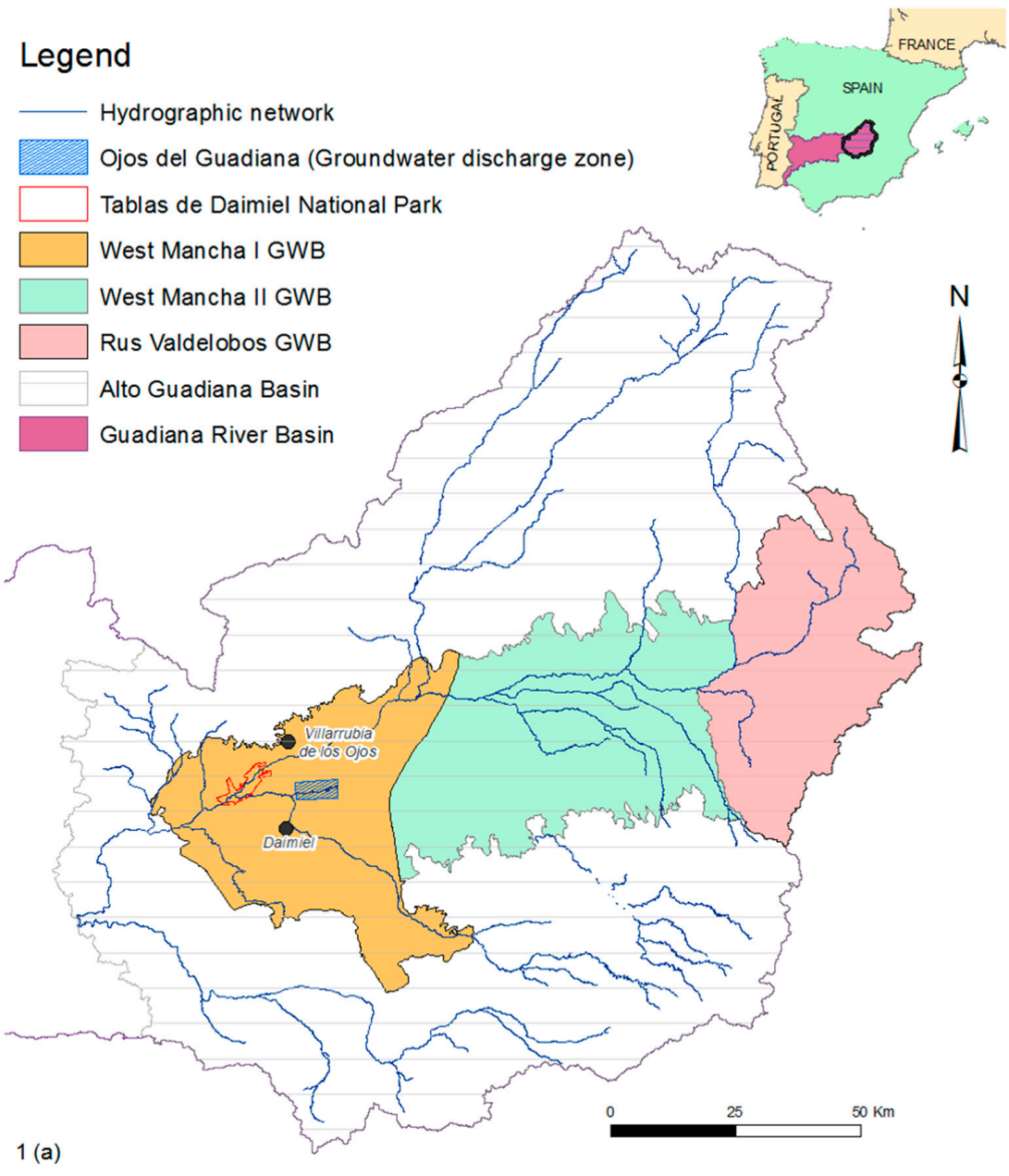

Figure 2. Groundwater bodies of the central area of the Guadiana river high basin.

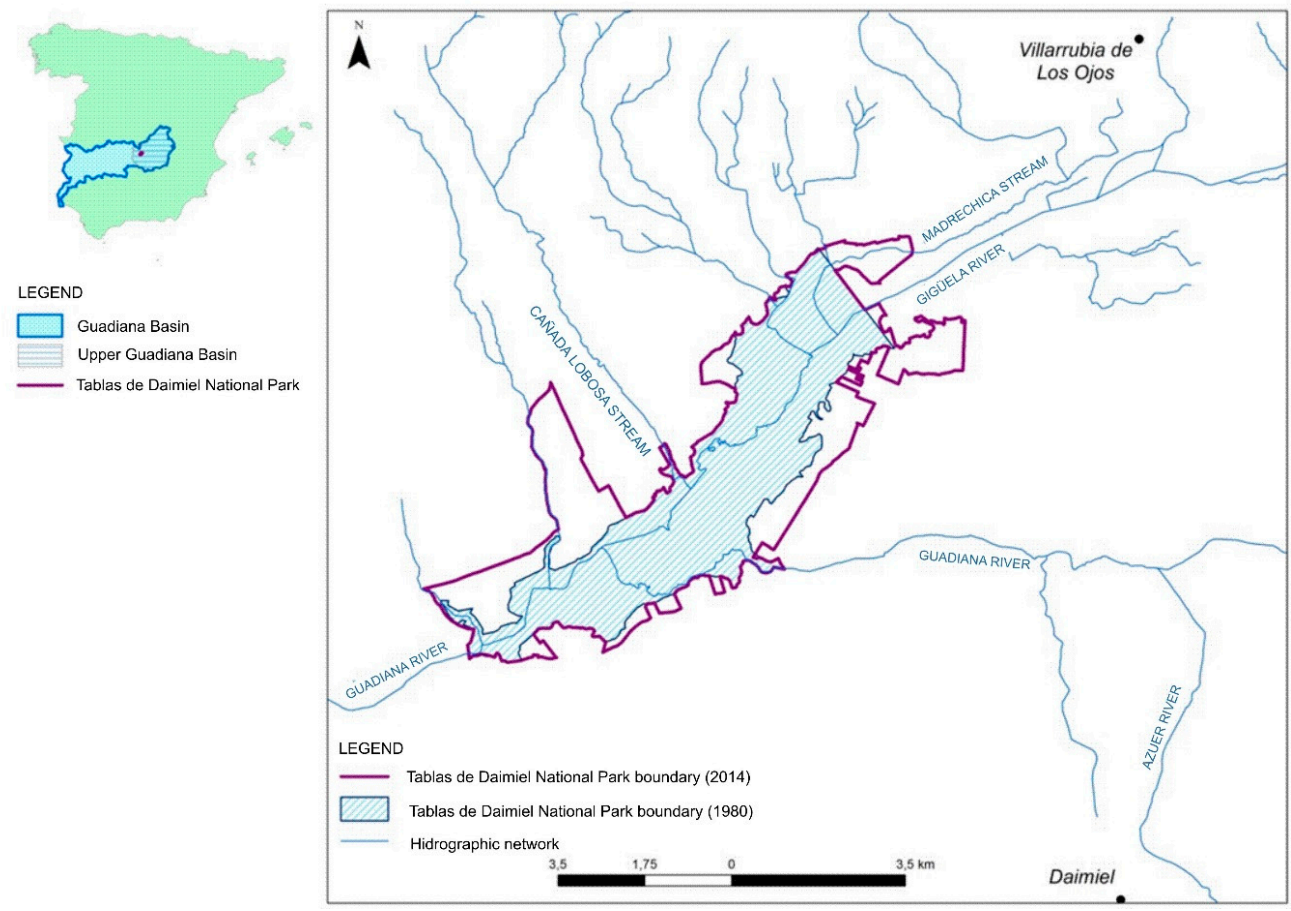

Figure 3. Boundaries of Las Tablas de Daimiel National Park and main river courses in the vicinity. 


\subsection{Flora and Fauna Associated with the TDNP}

The species of the genus Chara are the most abundant of the floating or submerged aquatic vegetation in calcareous oligomesotrophic waters. On considering the emergent vegetation it is worth highlighting the communities of "masiega" [Cladium mariscum (L.) Pohl], which is the largest "masegar" in Western Europe. The halophytic vegetation is mainly represented of the communities Juncetalia maritimi Br..Br-Bl \& O. Bolós and Limonietalia Br..Bl \& O. Bolós, with a high presence of Salicornia. It is also worth mentioning the presence of Ranunculus trichophyllus Chaix., Veronica Anagallis-aquatica L., Limonium ssp., Juncus maritimus L., Tamarix gallica L., T. canariensis Willd, and Salsola vermiculatata L., amongst others. Common reed and cattail are the major species within the associated vegetation $[14,15]$ and, to a lesser extent, C. mariscus and Thypa domingensis. The "tarayal" constitute the existing arboreal community.

The fauna that stand out in the wetland consist of aquatic species: anatidae (red duck, brown duck, bigeye, spoon duck), ardeidae (imperial heron, common martinete) and waders (stork, avocet). Finally, various species of amphibians, reptiles, fish, and mammals (for example, the otter) are present.

\section{Material and Methods}

The research was conducted in the floodplain of TDNP. The materials used include topographic and geological maps, a GPS unit, altimeter, Munsell Soil Color Chart, digital camera, bags and ring samples, knives, and tools for analysis of the chemical properties. All soil samples (from 24 soil profiles into the park, and 43 soils samples of the inundated area of the wetland), were dried at room temperature $\left(25^{\circ} \mathrm{C}\right)$ to constant weight and carefully sieved through a 2-mm mesh. Soil analysis included soil texture (hydrometer method). The analysis for determining the total major chemical element contents were determined by X-ray fluorescence (XRF) spectrometry using a total reflection fluorescence XRF system.

Spatial variability of the elements was produced by processing data using the IBM software SPSS v.21. The GIS software of choice for data integration was ArcGis v.10.2. The method chosen was processed by the algorithm IDW (inverse distance weighted) and calculations were initially performed with all points of the database.

\section{Results}

\subsection{Soils Type}

According to Jiménez-Ballesta [32], soils in the flood zone are mainly Histosols [33,35] and because they are often submerged (in flood channels, depressions, and ditches) for prolonged periods with a high density of vegetation, they have high organic carbon contents. There are also soils with redoximorphic features, Aquepts or Aquents by Soil Survey Staff [33] or Gleysols by FAO-UNESCO-ISSS [35]. A large group of Soil Taxonomy [33] has been found outside the flood zone in the National Park and these include Entisols such as Psamment (Xeropsamment) and Orthent (Xerorthent) and Inceptisols that include Xerepts (Calcixerepts and Haploxerept). According to the criteria of FAO-ISRIC-ISSS [35] the main groups of soil are Calcisols, Cambisols, Arenosols, Histosols, and Regosols. In some cases there may be Solonchaks but Calcisols are dominant. On considering a greater area of the park, it would be necessary to include the presence of Luvisols [35].

\subsection{Soil Properties}

The differences found in terms of various parameters, such as organic matter content and electrical conductivity, are attributed to differences in the formation factors that are fundamentally related to the topography of the flood plain. These differences in turn cause hydrological differences [36-39]. These authors showed that a long period of flooding with decelerated flow rates, including stagnant water, 
results in sedimentation of mainly fine-grain sediments along with considerable amounts of organic matter. Thus, for example, the dominant textures are sandy, followed by sandy loams, clayey, loamy and loamy-clay (Figure 4).

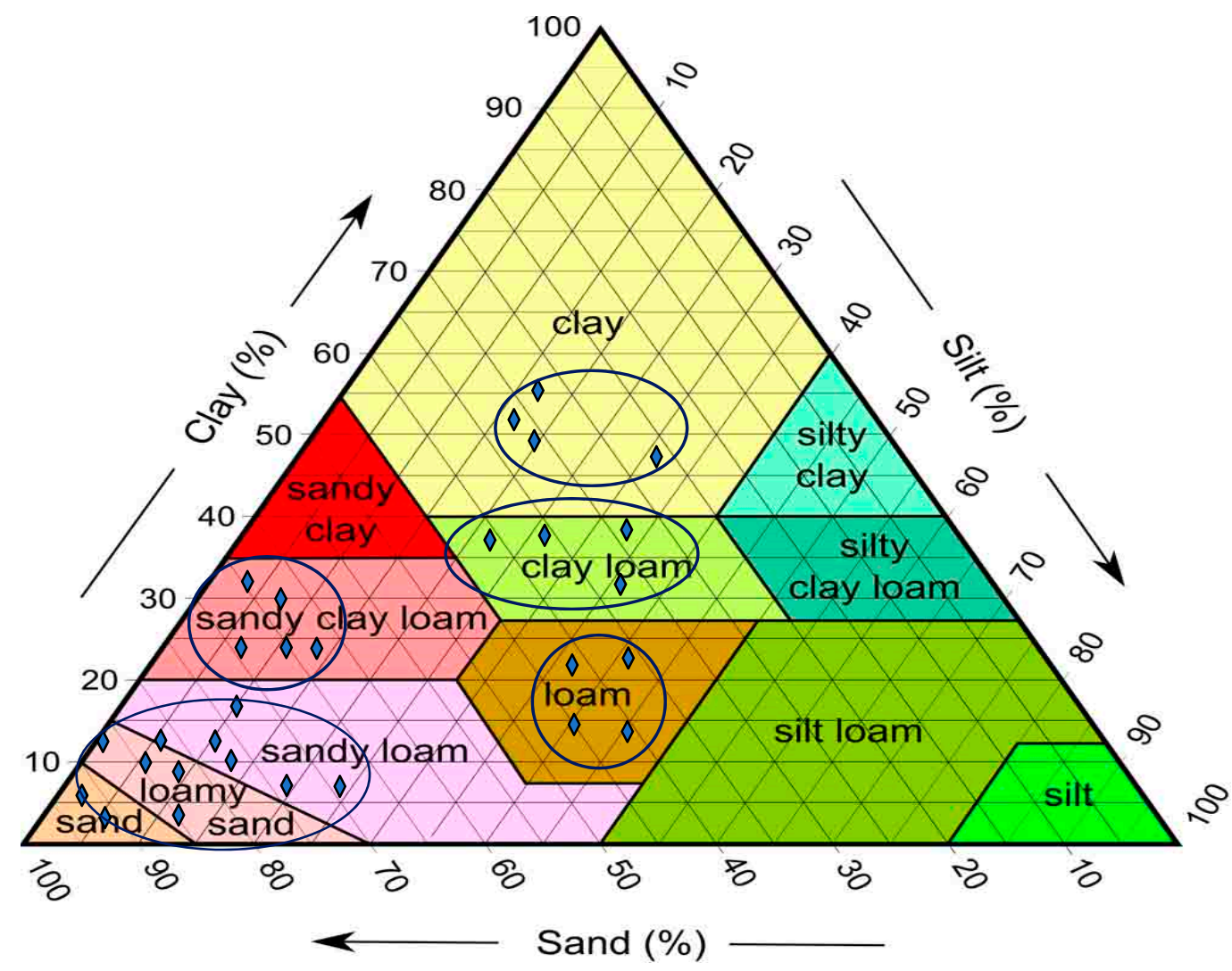

Figure 4. Textures found in the soils of the Tablas de Daimiel National Park (TDNP) flood zone.

The concentrations of $\mathrm{Si}, \mathrm{Al}, \mathrm{Fe}$, and $\mathrm{Ti}$ are provided in Figure 5. The Si content varies between 13.50 and $274.93 \mathrm{~g} \cdot \mathrm{kg}^{-1}$ (average $66.03 \mathrm{~g} \cdot \mathrm{kg}^{-1}$ ), while the Al concentration is between 2.12 and

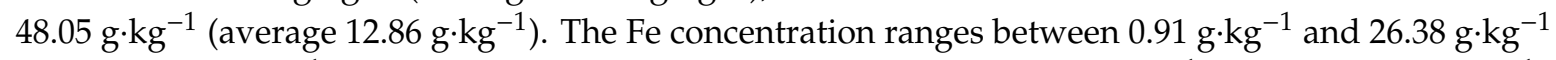
(average $7.74 \mathrm{~g} \cdot \mathrm{kg}^{-1}$ ) and the range for $\mathrm{Ti}$ is between 0.24 and $5.58 \mathrm{~g} \cdot \mathrm{kg}^{-1}$ (average $2.10 \mathrm{~g} \cdot \mathrm{kg}^{-1}$ ). $\mathrm{Si}$ and $\mathrm{Al}$ show a similar spatial variability, although four sections located in a transversal manner to the course of the river can be distinguished. In contrast, iron has greater spatial variability due to the different redox conditions of the area.

The concentrations determined for $\mathrm{Ca}, \mathrm{Mg}, \mathrm{K}$, and $\mathrm{Mn}$ differ markedly. The range for $\mathrm{Ca}$ is between $49.06 \mathrm{~g} \cdot \mathrm{kg}^{-1}$ and $352.07 \mathrm{~g} \cdot \mathrm{kg}^{-1}$ (average $203.51 \mathrm{~g} \cdot \mathrm{kg}^{-1}$ ) and for $\mathrm{Mg}$ the values are between $6.03 \mathrm{~g} \cdot \mathrm{kg}^{-1}$ and $19.28 \mathrm{~g} \cdot \mathrm{kg}^{-1}$ (average $8.59 \mathrm{~g} \cdot \mathrm{kg}^{-1}$ ). The $\mathrm{K}$ concentration is between $1.25 \mathrm{~g} \cdot \mathrm{kg}^{-1}$ and $19.34 \mathrm{~g} \cdot \mathrm{kg}^{-1}$ (average $6.75 \mathrm{~g} \cdot \mathrm{kg}^{-1}$ ). The concentration of $\mathrm{Mn}$ is between $0.43 \mathrm{~g} \cdot \mathrm{kg}^{-1}$ and $7.64 \mathrm{~g} \cdot \mathrm{kg}^{-1}$ (average $1.55 \mathrm{~g} \cdot \mathrm{kg}^{-1}$ ). The spatial distributions of these elements are represented in Figure 5 . It can be observed that $\mathrm{Ca}$ and $\mathrm{Mg}$ show a relatively similar pattern, with concentrations detected towards the lower and higher exits close to the entrance of the Park. K shows a highly variable pattern from input to output, whereas Mn shows a relatively consistent trend-except close to the entrance area of the river Guadiana, where the highest values are found for this element. 

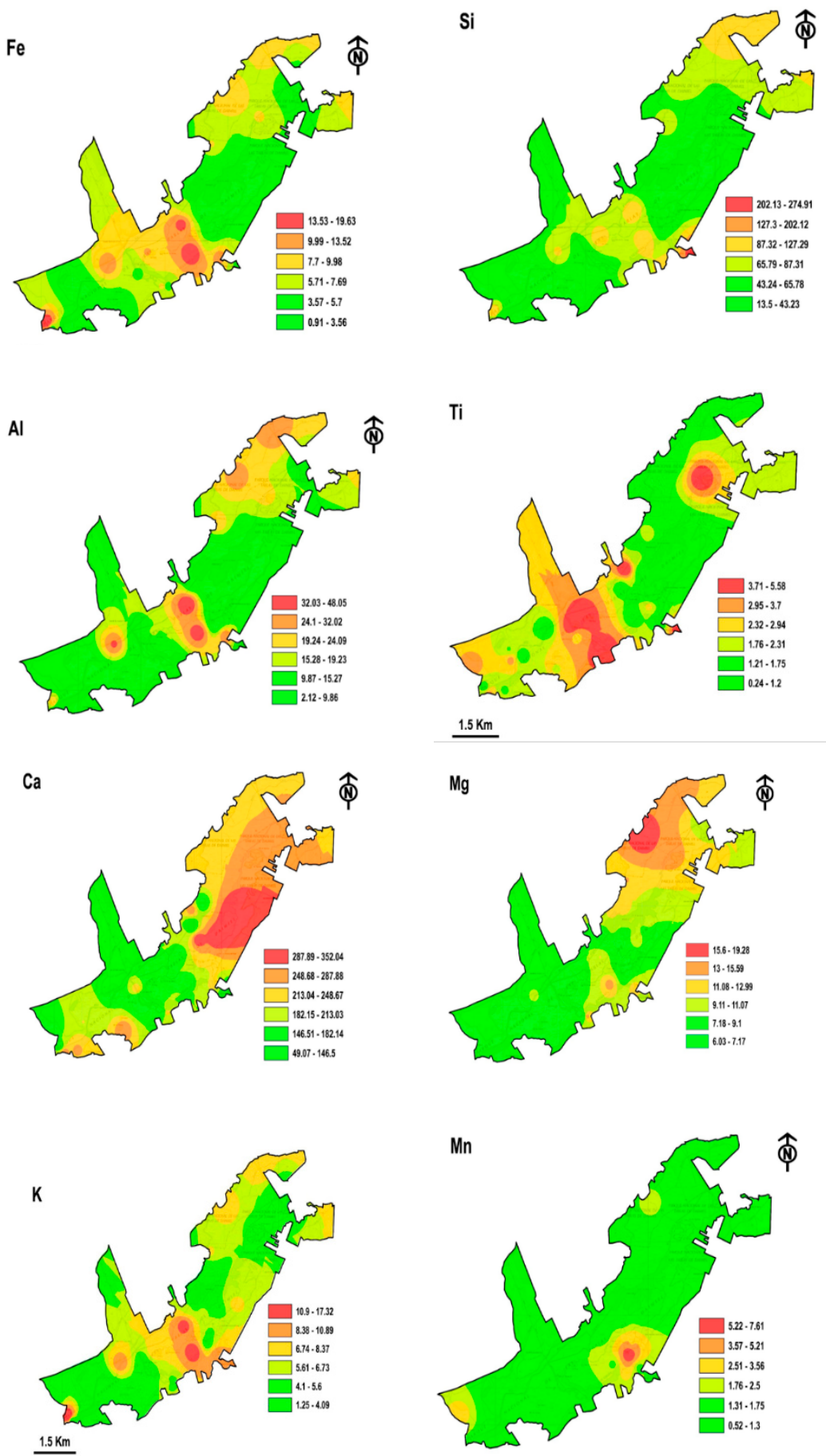

Figure 5. Spatial variability of $\mathrm{Fe}, \mathrm{Si}, \mathrm{Al}, \mathrm{Ti}, \mathrm{Ca}, \mathrm{Mg}, \mathrm{K}$, and $\mathrm{Mn}\left(\mathrm{g} \cdot \mathrm{kg}^{-1}\right)$ in the soils of the flood zone of the TDNP.

\section{Discussion}

\subsection{Functions of TDNP}

Based on the work carried out previously by us and taking into consideration the criteria of Prasad et al. [40], the functions of the Tablas of Daimiel National Park can be summarized in the following way: water recharge, providing natural purification and storage of freshwater for humans and wildlife; the park has been-and remains—very important from the point of view of environmental science; protects the natural shoreline from wave action and erosion and aids natural flood reduction 
and control through water storage and retention; supports a habitat for a wide range of waterfowl, flora, furbearers, reptiles, and fish, preserving the biodiversity and vitality of the species; serves as an important source of oxygen, as well as providing a habitat for a wide range; and finally, has historically acted as a natural storage base for carbon, sequestered, and it restores and rebuilds degraded carbon pools. Although this wetland has currently less economic importance than in the past, it also still has socioeconomic functions: it has been and is very attractive for tourism and recreational use; it can be used as a source of peat for horticultural and agricultural applications, although this use is not advised; and finally, the area is a rich and varied landscape that serves as a valued aesthetic resource.

\subsection{Main Causes of the Degradation of the TDNP}

Large areas that form part of wetlands have been destroyed all over the world, thus decreasing the ecosystem services they provide to society [41]. This process is becoming more intense due to land management [42] or the direct release of human waste [43].

As with other wetlands, degradation of the TDNP has been relatively rapid, especially when compared to other types of ecosystems. Activities that result in the loss and degradation of wetlands include agriculture, commercial and residential development, road construction, resource extraction, industrial siting, processes, and waste. The primary pollutants that cause degradation of the TDNP are sediment, nutrients, pesticides, and some trace elements. Indeed, the expansion of traditional and modern agriculture, together with urbanization and industrialization, and a lack of institutional policies and agreements are probably the factors that trigger the degradation of the TDNP, with the elimination of waste probably being the main human cause of loss of quality.

The TDNP wetland was declared a National Park in 1973, a Biosphere Reserve in 1981, and it was included in the Ramsar Convention in 1982. The balance between humans and the wetland was broken decades ago. Actions to dry the Mancha Húmeda (Wet Spot) preceded the intensive exploitation of underground water resources. In this way, the Park has undergone a series of changes due to a combination of factors, which include agricultural irrigation, and these activities have led to the overexploitation of the aquifer that feeds the Park.

The degradation outlined above began in the 1970s. In 1966, Las Tablas de Daimiel was classified as a protected area through the declaration as a National Hunting Reserve (Law 37/1966 of 31 May) for an area of 2750 hectares. In the summer of 1971, the wetlands dried up for the first time due to the plans to increase the area devoted to agriculture and to diminish the effect of diseases linked to this type of land. The desiccation was caused by the excavation of the Guadiana channel, which was significantly lower than that of the river, through which the waters that entered Las Tablas from Los Ojos del Guadiana and the Azuer river flowed. The decision provoked considerable alarm in the Spanish conservation movement.

The intensive use of groundwater has favored two important geomorphological, environmental, and landscape changes. The first change was the general subsidence of the land as a result of the loss of groundwater due to the decrease in the piezometric level, which also favored self-combustion of the peat deposited in the subsoil. The second change was the occurrence of ground collapses, with an irregular spatial distribution conditioned by the geometry of the sedimentary bodies. When the weight of the suspended materials above the cavities exceeds their mechanical resistance, collapse occurs and this process manifests itself in the surface as a circular or semicircular hole. In the TDNP and its surroundings, a total of 34 collapses with different origins have been documented [34].

The situation continued to deteriorate as a result of the 'sanitation' work and a year later, in the summer of 1972, several emergency measures had to be adopted in the face of the critical situation that the wetland was experiencing. On 30 July 1973, Decree 1874/1973, dated 28 June, was published and it designated a portion of these lands as Las Tablas de Daimiel National Park, with an area of 1874 hectares, which contained an integral waterbird reserve area. However, in the area of Los Ojos del Guadiana, the desiccation work continued. In 1980, this area was reclassified and the park then covered 
an area of 1928 ha. Finally, on 10 January 2014, the Council of Ministers approved the extension of the limits of the TDNP to the current 3030 ha [44] (Figure 6).

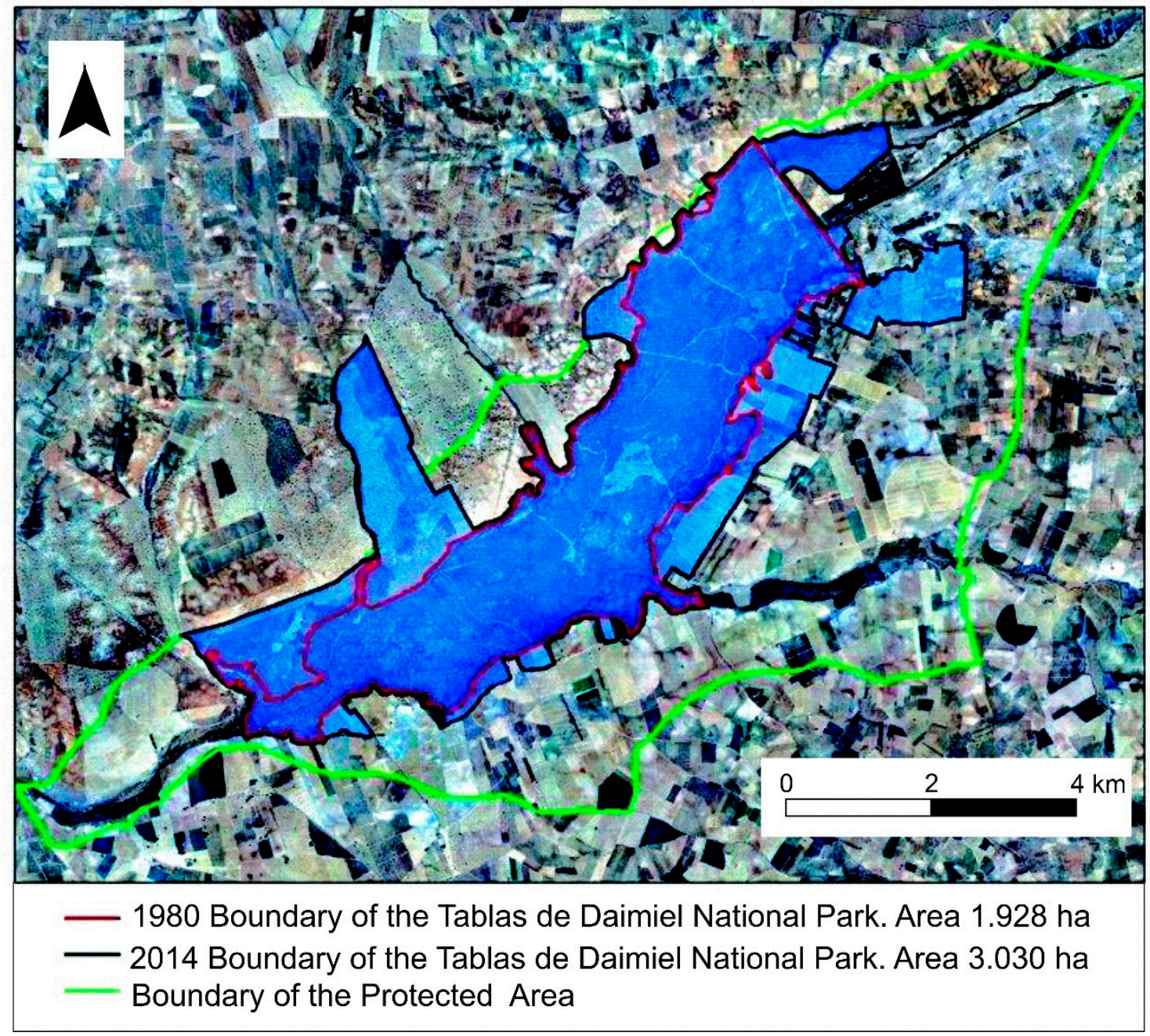

Figure 6. Limits and extent of Las Tablas de Daimiel National Park.

The drying works clearly left significant scars on the surface of the Park and its surroundings and modified the hydrology in a remarkable way, but the most important threat to the wetland, which has jeopardized its survival on several occasions, has been-and remains - the unsustainable use of underground water resources for agricultural purposes, which began in the mid-1970s. These resources are stored in the Aquifer System 23 [45], which is currently divided into three bodies of groundwater according to the Hydrological Plan of the Guadiana Hydrographic Demarcation 2009/15, RD 354/2013, of 17 May, and RD 1/2016, of 8 January, BOE of 19 January, which updates the Plan for the hydrological planning cycle 2015/21.

The Tablas de Daimiel National Park was significantly altered by its natural conditions of superficial drainage. Additionally, there has been intensive use of groundwater for agricultural purposes that led to an average decrease in the piezometric level of about $30 \mathrm{~m}$ in the period 1980/96 [16]. This situation remained until January 2012. As a consequence of the humid climatological sequence 2009/13, some of Los Ojos del Guadiana reappeared and this produced surface runoff and led to a maximum contribution of groundwater to the river in the section between La Máquina mill and Nuevo mill, which is located immediately after the confluence with the Azuer river. It has been estimated at around $11 \mathrm{Mm}^{3}$ $\left(11 \times 10^{6} \mathrm{~m}^{3}\right)$ in 2014 . Upstream of this point, in the Guadiana River, surface runoff could not be 
measured and the contribution of underground water was limited to flooding of the land. The volume of discharge was 78\% less than the flow drained permanently under natural conditions.

In 1983, the water stopped flowing in Los Ojos del Guadiana and this left the wetland without its main water supply. In an effort to alleviate this situation, various actions were carried out that further transformed the wetland. In 1985, the Puente de Navarro dam was built, several water transfers from the Tajo river basin were approved between 1988 and 2009, with volumes between 6 and $20 \mathrm{Mm}^{3}$ per year, and another small dam was built in 1987 (the Morenillo) to facilitate the transfer of the flood water over a wider area.

The diversion of the water flows takes place from the Tajo-Segura Aqueduct to the Park, thus taking advantage of its passage over the Valdejudíos stream, a tributary of the Gigüela. Specific legislation was required and Law 13/1987, of 17 July, allowed the experimental derivation of up to $60 \mathrm{Mm}^{3}$ in three years without these water resources being used for purposes other than those of an environmental nature.

In the TDNP, there are severe water quality problems due to the diffuse contamination produced by agricultural practices and the occasional discharge of water with a high organic load into the Gigüela and Guadiana rivers. The causes of this problem are the insufficient or malfunctioning sewage treatment plants in nearby urban centers, the uncontrolled dumping of agro-food industries or intense rains.

The main concern since the declaration of the National Park has been the lack of water and the sporadic occurrence of polluting episodes, which have left their mark on the sediments [17] and have kept the flooded areas in a state of permanent alert.

After the 2009-2013 wet period, the TDNP reached the maximum flood surface area (2020 ha) with a volume of stored water of around $15 \mathrm{Mm}^{3}$, which is a significantly lower value than for an unmodified regime. It appears that total recovery of the hydrogeological system is unlikely. The maximum flow occurred during a short period of time and this reduced steadily to zero in the months of low water from 2016 to 2018.

Despite the natural values achieved, the TDNP is under strong anthropic pressure and there is consequent degradation. There is a shared vision that the TDNP is going through a state of palpable degradation, as evidenced by the turbidity of the water, the decay or loss of traditional plant species, the presence of invasive species, the increase in potentially toxic elements, and the transformation from a natural discharge area of groundwater of a large regional aquifer to a recharge area by infiltrating the water stored in the wetland. These are direct consequences of the decrease in the piezometric level produced in recent decades.

As with many other wetlands in the world, the main threats to the TDNP are the overexploitation of its resources, the pollution caused by agricultural and industrial processes and the modification of the natural flow of groundwater. All of these are related to the increase in the use of water resources (both for supply and for agricultural and industrial uses), habitat degradation, including the appearance of invasive species, and climate change. Jiménez-Ballesta et al. [19] published data for several pollutants that penetrate the TDNP; in some cases, these emanate from point sources (nearby sewage treatment plants) whereas in other cases they are diffuse, i.e., agriculture, which favors the loading of contaminants from the addition of pesticides and/or fertilizers.

Periodic flooding, concurrent erosion, and sedimentation control the accumulation and dynamics of substances, including the content and chemistry of pollutants. The importance of the soil to control the pollutants and the quality of the water has been sowed [3]. In general, concentrations of pollutants often reveal some particular variability and the existence of relatively high levels of certain elements, as is the case of bromine [19]. Primarily the sources of some major and trace elements in soils are due to the nature of alluvial material, but in some cases they arise from industrial and agricultural activities [18,19]. In any case, one must consider that the availability of trace elements in soils depends on a number of factors such as their solubility in water, their source and their nature. 
Oxidation and reduction reactions are of prime importance, particularly in wetland ecosystems such as TDNP. Water saturation during extended periods usually results in changes in the chemical properties of sediments and soils, as well as in microbial populations and processes. Soils tend to undergo a series of sequential redox reactions when the redox status of the soil changes from aerobic to anaerobic conditions during flooding. Major reactions include denitrification, manganic manganese $[\mathrm{Mn}(\mathrm{IV})]$ reduction, ferric iron [Fe(III)] reduction, sulfate $\left(\mathrm{SO}_{4}{ }^{2-}\right)$ reduction, and methanogenesis. These processes are catalyzed by microorganisms [43] and have previously been studied in the TDNP [18] and other areas [46-49].

\subsection{Management Approaches fir TDNP Wetland Conservation}

In order to address the problems that threaten the TDNP, it is necessary to disseminate the scientific knowledge and the opinions of the experts to the inhabitants of the area. Only with knowledge of the dynamics of the system in its biophysical, socioeconomic, and institutional aspects, which would allow an evaluation of the viability, acceptance, and preference of the proposed solutions, will it be possible to save the TDNP.

Currently, the conservation strategy for this ecosystem is insufficient. We suggest the need to control and prohibit any dumping of any type of waste in the park or in its vicinity, since the review of some data reveals high levels of anthropogenic contamination. It would also be useful to promote a public awareness program.

Therefore, it would be necessary to reverse more than 40 years of environmental degradation by restoring the water balance, the native vegetation, and contributing to human habitability.

Some conservation generic measures should involve the following: ensure a sheet of water, with good chemical quality, that allows the development and maintenance of submerged and floating vegetation, thus maintaining the halophilic habitats linked to the wetland. Control of allochthonous species that may be interfering with the natural dynamics of populations. Additionally, physical-chemical controls of the waters and soils of the wetland with respect to parameters related to soil/water quality should be carried out.

Land degradation neutrality as is focused on in the UN Sustainable Development Goals (SDGs) is a technical term referring to intentional actions to avoid, reduce, and reserve degradation of the land [50]. In this sense, communication, education, participation, and citizen awareness are all necessary and these could be achieved by the development of informative material that highlights the high value of the natural space.

Climate change predictions show that the arid or semi-arid regions of Africa in the latitudes around the Tropics of Capricorn and Cancer will become drier [51]. This situation is similar to that in the La Mancha natural region, so the future of these wetlands is allied to human well-being. In this way, Governance systems play a key role in the sustainable management of resources. This is not unique; is part of a worldwide process of land degradation [52].

\section{Conclusions}

If conservation measures for the TDNP are not taken, its degradation and destruction will continue. In this way, we suggest the control and prohibition of any type of waste disposal in the park or in its vicinity. It would also be useful to carry out a public awareness program. The scientific understanding of the benefits that this wetland provides to society has already been transferred not only to the public in general, but also to decision makers. It is necessary to understand the dynamics of power between rural and urban perspectives and the concerns of public and private property rights to frame appropriately the conservation around this wetland in the public space. 
Author Contributions: All authors wrote the paper contributing by writing different sections of the work. S.B.-M. and F.J.G.-N. worked together to do the field research sampling and to analyze the data. M.M. wrote about the geological and hydrological data, as well as interpretation of wetland history degradation. Finally, R.J.-B. provided the soil data and also conceived and designed the activities. All authors have equally participated in the revisions and the final editing of this text prior to its submission.

Funding: This Research was funded by Organismo Autonomo Parques Nacionales (Autonomous Organism National Parks) of Spain (OAPN).

Acknowledgments: The authors are grateful to the Organismo Autonomo Parques Nacionales (Autonomous Organism National Parks) of Spain (OAPN) for providing financial assistance.

Conflicts of Interest: The authors declare no conflict of interest.

\section{References}

1. Dudgeon, D.; Arthington, A.H.; Gessner, M.O.; Kawabata, Z.I.; Knowler, D.J.; Lévêque, C.; Naiman, R.J.; Prieur-Richard, A.H.; Soto, D.; Stiassny, M.L.; et al. Freshwater biodiversity: Importance, threats, status and conservation challenges. Biol. Rev. 2006, 81, 163-182. [CrossRef] [PubMed]

2. Millennium Ecosystems Assessment. Ecosystems and Human Well-Being: Wetlands and Water Synthesis. 2005. Available online: http://www.millenniumassessment.org/documents/document.358.aspx. pdf (accessed on 15 July 2016).

3. Keesstra, S.; Mol, G.; de Leeuw, J.; Okx, J.; de Cleen, M.; Visser, S. Soil-related sustainable development goals: Four concepts to make land degradation neutrality and restoration work. Land 2018, 7, 133. [CrossRef]

4. Crooks, H.D.; Tamelander, J.; Laffoley, D.; Vandever, J. Mitigating Climate Change Through Restoration and Management of Coastal Wetlands and Near-Shore Marine Ecosystems: Challenges and Opportunities; Environment Department Paper 121; World Bank: Washington, DC, USA, 2006; p. 1.

5. Van Asselen, S.; Verburg, P.H.; Vermaat, J.E.; Janse, J.H. Drivers of wetland conversion: A global meta-analysis. PLoS ONE 2013, 8, e81292. [CrossRef] [PubMed]

6. Davidson, N. How much wetland has the world lost? Long-term and recent trends in global wetland area. Mar. Freshw. Res. 2014, 65, 934-941. [CrossRef]

7. Wang, J.; Lu, X.; Jiang, M.; Li, X.Y.; Tian, J.H. Fuzzy synthetic evaluation of wetland soil quality degradation: A case study on the Sanjiang Plain, Northeast China. Pedosphere 2009, 19, 756-764. [CrossRef]

8. Li, J.W.; Wang, L.; Wang, W. Characterization of degradation of wetland plant communities on floodplain in typical steppe region of Inner Mongolia Plateau, China. Chin. J. Plant Ecol. 2012, 36, 10-18. [CrossRef]

9. Cirujano, S.; Velayos, M.; Castilla, F.; Gil, M. Criterios Botánicos Para la Valoración de las Lagunas y Humedales Españoles (Península IBÉRICA y Baleares); Colección Técnica ICONA-CSIC: Madrid, Spain, 1992; 456p.

10. Casado, S.; Montes, C. Guía de los Lagos Y Humedales de España; Reyero, J.M., Ed.; Reyero, J.M. Editor: Madrid, Spain, 1995; p. 255.

11. Cirujano, S.; Casado, C.; Bernués, M.; Camargo, J.A. Ecological study of Las Tablas de Daimiel National Park (Ciudad Real, Central Spain): Differences in water physico-chemistry and vegetation between 1974 and 1989. Biol. Conserv. 1996, 75, 211-215. [CrossRef]

12. Hollis, G.E.; Finlayson, C.M. Ecological Change in Mediterranean Wetlands. In Monitoring Mediterranean Wetlands: A methodological Guide; Tomás Vives, P., Ed.; MedWet Publication; Wetlands International: Slimbridge, UK; ICN: Lisboa, Portugal, 1996; pp. 5-24.

13. Tomás Vives, P. (Ed.) Monitoring Mediterranean Wetlands: A Methodological Guide; MedWet Publication; Wetlands International: Slimbridge, UK; ICN: Lisboa, Portugal, 1996; 150p.

14. Alvarez-Cobelas, M.; Cirujano, S.; Sanchez-Carrillo, S. Hydrological and botanical man-made changes in the Spanish wetland of Las Tablas de Daimiel. Biol. Conserv. 2001, 97, 89-98. [CrossRef]

15. Cirujano, S.; Medina, L. Plantas Acuáticas de las Lagunas Y Humedales de Castilla-La Mancha; Junta de Comunidades de Castilla-La Mancha -CSIC: Castilla-La Mancha, Spain, 2002.

16. Ballesteros, B.J.; Domínguez, J.A.; Díaz-Losada, E.; García, O. Mediterranean wetland and associated aquifers. Hidrogeology of Pego-Oliva Natural Park (Alicante-Valencia, Spain). Bol. Geol. Min. 2009, 120, 459-478.

17. Mejías, M. (Ed.) Las Tablas y los Ojos del Guadiana: Agua, paisaje y gente; Instituto Geológico y Minero de España, Organismo Autónomo Parques Nacionales: Madrid, Spain, 2014; 360p, ISBN 978-84-7840-927-3. 
18. Jiménez-Ballesta, R.; García-Navarro, F.J.; Bravo, S.; Amorós, J.A.; Perez-de los Reyes, C.; Mejias, M. Environmental assessment of potential toxic trace element contents in the inundated floodplain area of Tablas de Daimiel wetland (Spain). Environ. Geochem. Health 2016, 39, 1159-1177. [CrossRef]

19. Jiménez-Ballesta, R.; García-Navarro, F.J.; Bravo Martín-Consuegra, S.; Pérez-de-los-Reyes, C.; Amorós Ortíz-Villajos, J.A.; Fernández San Miguel, M. The impact of the Storage on Nutrients and Other Trace Elements on the Degradation of a Wetland. Int. J. Environ. Res. 2018, 12, 87-100. [CrossRef]

20. Garcia-Navarro, F.J.; Perona, E.; Cubero, S.; Allende, F.; Bravo, S.; Jiménez-Ballesta, R. Primary Producers and Anthropic Signs Related to the Flood Plain Soils of the Tablas de Daimiel Wetland. Geosciences 2018, 8 , 106. [CrossRef]

21. Keesstra, S.D.; Geissen, V.; Mosse, K.; Piiranen, S.; Scudiero, E.; Leistra, M.; van Schaik, L. Soil as a filter for groundwater quality. Curr. Opin. Environ. Sustain. 2012, 4, 507-516. [CrossRef]

22. General Directorate for Forest Policy and Natural Spaces. Dirección General de Política Forestal Y Espacios Naturales. Consejería de Agricultura, Medio Ambiente y Desarrollo Rural. Junta de Comunidades de Castilla-La Mancha. Plan de Gestión de Tablas de Daimiel, es0000013 (Ciudad Real). 2015. Available online: http: //www.castillalamancha.es/sites/default/files/documentos/paginas/archivos/doc_2_es0000013.pdf (accessed on 19 May 2019).

23. Global Nature Fund. Restauración de Humedales - Manejo Sostenible de Humedales y Lagos Someros. Manual Para La Elaboración de un Plan de Gestión. 2004. Available online: http://ec.europa.eu/environment/life/project/ Projects/index.cfm?fuseaction=home.showFile\&rep=file\&fil=LIVING_LAKES_manual_ES.pdf (accessed on 20 May 2019).

24. Ostrovskaya, E.; Douven, W.; Schwartz, K.; Pataki, B.; Mukuyu, P.; Kaggwa, R.C. Capacity for sustainable management of wetlands: Lessons from the WET win project. Environ. Sci. Policy 2013, 34, 128-137. [CrossRef]

25. García Rodríguez, M.; Llamas, M.R. Cambios paisajísticos en el Alto Guadiana causados por la explotación intensiva e incontrolada de aguas subterráneas. Actas de las VI Jornadas sobre el Paisaje. Segovia 1993, 1,91-102.

26. Álvarez-Cobelas, M.; Cirujano, S. Las Tablas de Daimiel. Ecología Acuática y Sociedad; Organismo Autónomo de Parques Nacionales: Madrid, Spain, 1996; p. 371.

27. García Rodríguez, M. Hidrogeología de las Tablas de Daimiel y de Los Ojos Del Guadiana. Bases Hidrogeológicas Para Una Clasificación Funcional de Humedales Ribereños. Ph.D. Thesis, Universidad Complutense de Madrid, Madrid, Spain, 1996; p. 438, 4 Anejos.

28. Cirujano, S.; Alvarez Cobelas, M. Asesoramiento Ambiental A La Dirección del Parque Y Diseño de Actuaciones Para La Recuperación Ambiental Gradual de Las Tablas de Daimiel (2008-2010); Organismo Autónomo Parques Nacionales: Madrid, Spain, 2010; 323p.

29. Del Pozo, J.; Mejías, M. Los Ojos del Guadiana y del Gigüela: El resurgir de una masa de agua subterránea declarada "en riesgo". Boletín Geológico Y Min. 2017, 128, 517-539. [CrossRef]

30. Martínez-Cortina, L.; Mejías, M. Perspectivas de recuperación del sistema hidrológico de la cuenca alta del Guadiana ante diferentes escenarios meteorológicos y de explotación. In Actas Congreso Ibérico sobre las aguas subterráneas: Desafíos de la gestión para el Siglo XXI; Asociación Internacional de Hidrogeólogos-Grupo Español: Zaragoza, Spain, 2012.

31. Mejías, M.; López-Gutiérrez, J.; Martínez-Cortina, L. Características hidrogeológicas y evolución piezométrica de la Mancha Occidental. Influencia del periodo húmedo 2009-2011. Boletín Geológico Y Min. 2012, 123,91-108.

32. Jiménez-Ballesta, R. Los suelos del Parque Natural de Las Tablas de Daimiel; Universidad Autónoma de Madrid: Madrid, Spain, 2014; 104p.

33. Soil Survey Staff. Keys to Soil Taxonomy, 7th ed.; USDA-NCRS: Washington, DC, USA, 2006.

34. Bórnez, K.; Mejías, M.; Camuñas, C.; del Pozo, J.; del Moral, A. Inventario, clasificación y génesis de los colapsos del terreno en la Masa de Agua Subterránea Mancha Occidental I. Boletín Geológico Y Min. 2017, 128, 43-68.

35. FAO-UNESCO-ISSS. World Reference Base for Soil Resources. A Framework for International Classification, Correlation and Communication; World Soil Resources Reports 103; FAO: Rome, Italy, 2006; 132p. 
36. Rinklebe, J. Differenzierung von Auenböden der Mittleren Elbe und Quantifizierung des Einflusses von Deren Bodenkennwerten Auf Die Mikrobielle Biomasse und Die Bodenenzymaktivitäten von b-Glucosidase, Protease und Alkalischer Phosphatase. Ph.D. Thesis, Martin-Luther-Universität Halle-Wittenberg, Halle-Wittenberg, Germany, 2004; 113p. With English summary.

37. Rinklebe, J.; Franke, C.; Neue, H.U. Aggregation of floodplain soils as an instrument for predicting concentrations of nutrients and pollutants. Geoderma 2007, 141, 210-223. [CrossRef]

38. Bockheim, J.G. Soil endemism and its relation to soil formation theory. Geoderma 2005, 129, $109-124$. [CrossRef]

39. Lin, H.S.; Bouma, J.; Pachepsky, Y. Revitalizing pedology through hydrology and connecting hydrology to pedology. Geoderma 2006, 131, 255-256. [CrossRef]

40. Prasad, S.N.; Ramachandra, T.V.; Ahalya, N.; Sengupta, T.; Kumar, A.; Tiwari, A.K.; Vijayan, V.S.; Vijayan, L. Conservation of wetlands of India-A review. Trop. Ecol. 2002, 3, 173-186.

41. Gardner, R.C.; Barchiesi, S.; Beltrame, C.; Finlayson, C.M.; Galewski, T.; Harrison, I.; Paganini, M.; Perennou, C.; Pritchard, D.E.; Rosenqvist, A.; et al. State of the World's Wetlands and their services to people: A compilation of recent analyses. In Ramsar Scientific and Technical Briefing Note Number 7; Ramsar Convention Secretariat: Gland, Switzerland, 2015.

42. Junk, W.J.; An, S.; Finlayson, C.M.; Gopal, B.; Květ, J.; Mitchell, S.A.; Mitsch, W.J.; Robarts, R.D. Current state of knowledge regarding the world's wetlands and their future under global climate change: A synthesis. Aquat. Sci. 2013, 75, 151-167. [CrossRef]

43. Gell, P.; Mills, K.; Grundell, R. A legacy of climate and catchment change: The real challenge for wetland managemen. Hydrobiologia 2013, 708, 133. [CrossRef]

44. Carrasco, M. El Parque Nacional de Las Tablas de Daimiel. In Las Tablas y los Ojos del Guadiana: Agua, Paisaje y Gente; Mejías, M., Ed.; Instituto Geológico y Minero de España, Organismo Autónomo Parques Nacionales: Madrid, Spain, 2014; pp. 247-282.

45. ITGE. Sistema acuífero $n^{\circ}$ 23. Mancha Occidental; Serie: Manuales de utilización de acuiferos; ITGE: Madrid, Spain, 1989.

46. Patrick, W.H., Jr.; Jugsujinda, A. Sequential reduction and oxidation of inorganic nitrogen, manganese and iron in flooded soil. Soil Sci. Soc. Am. J. 1992, 56, 1071-1073. [CrossRef]

47. Ponnamperuma, F.N. The chemistry of submerged soils. Adv. Agron. 1992, 24, $29-96$.

48. Du Laing, D.; Rinklebeb, J.; Vandecasteelec, B.; Meersa, E.; Tacka, F.M.G. Trace metal behaviour in estuarine and riverine floodplain soils and sediments: A review. Sci Total Environ. 2008. [CrossRef] [PubMed]

49. Smith, C.J.; Delaune, R.D. Effect of rice plants on nitrification-denitrification loss of nitrogen under greenhouse conditions. Plant Soil 1984, 79, 287-290. [CrossRef]

50. Nicklin, S. A Better World. Volume 4. Actions and Commitments to the Sustainable Development Goals. Publisher Tutor Rose. United Nations. Ebook, ISBN 978-0-9956487-5-3. 2018. Available online: http://library.unccd.int/Details/books/992 (accessed on 18 May 2019).

51. Mitchell, S.A. The status of wetlands, threats and the predicted effect of global climate change: The situation in Sub-Saharan Africa. Aquat. Sci. 2013, 75, 95-112. [CrossRef]

52. Narany, T.S.; Aris, A.Z.; Sefie, A.; Keesstra, S. Detecting and predicting the impact of land use changes on groundwater quality, a case study in Northern Kelantan, Malaysia. Sci. Total Environ. 2017, 599, 844-853. [CrossRef]

(C) 2019 by the authors. Licensee MDPI, Basel, Switzerland. This article is an open access article distributed under the terms and conditions of the Creative Commons Attribution (CC BY) license (http://creativecommons.org/licenses/by/4.0/). 